\title{
A new spider species of the genus Cocalus C.L. Koch, 1846 (Araneae: Salticidae: Spartaeinae) from Western Ghats of India
}

\author{
Новый вид пауков из рода Cocalus C.L. Koch, 1846 (Araneae: \\ Salticidae: Spartaeinae) из Западных Гат Индии
}

\section{Puthoor Pattammal Sudhin ${ }^{1,5}$, Karunnappilli Shamsudheen Nafin ${ }^{1,2}$, Njarekkattil Vasu Sumesh ${ }^{1,3}$, Ambalaparambil Vasu Sudhikumar ${ }^{1,4}$ П.П. Судхин ${ }^{1,5}$, К.С. Нафин ${ }^{1,5}$, Н.В. Сумеш ${ }^{1,2}$, А.В. Судхикумар ${ }^{1,4}$}

\author{
${ }^{1}$ Centre for Animal Taxonomy and Ecology, Department of Zoology, Christ College (Autonomous), Irinjalakuda - 680 125, Kerala, India. \\ E-mails: Nafinks@gmail.com, 33sumeshvasu14@gmail.com, ${ }^{4}$ avsudhi@rediffmail.com \\ ${ }^{5}$ Corresponding author: sudhinpp@gmail.com
}

KEY WORDS: Aranei, jumping spider, description, distribution map, Kerala, Wayanad Wildlife Sanctuary. КЛЮЧЕВЫК СЛОВА: Aranei, паук-скакунчик, описание, карта распространения, Керала, Уэйнадский заповедник.

ABSTRACT. A new species of the jumping spider genus Cocalus C.L. Koch, $1846-$ C. lacinia sp.n. $\left(\mathrm{O}^{\top}+\right)$ - is diagnosed and described from the Wayanad Wildlife Sanctuary, Western Ghats, Kerala, India. A detailed morphological description, diagnostic features and illustrations of the copulatory organs of both sexes are given. The current distribution of the genus in India is mapped as well.

How to cite this article: Sudhin P.P., Nafin K.S., Sumesh N.V., Sudhikumar A.V. 2019. A new spider species of the genus Cocalus C.L. Koch, 1846 (Araneae: Salticidae: Spartaeinae) from Western Ghats of India // Arthropoda Selecta. Vol.28. No.1. P.125-130. doi: 10.15298/arthsel. 28.1.10

РЕЗЮМЕ. Диагностирован и описан новый вид пауков-скакунчиков из рода Cocalus C.L. Koch, 1846 из Уэйнадского заповедника, Западные Гаты, Керала, Индия: C. lacinia sp.n. ( $\left.\bigcirc^{7}\right)$. Приведены детальное морфологическое описание, диагностические признаки и иллюстрации копулятивных органов обоих полов. Также прокартировано современное распространение рода в Индии.

\section{Introduction}

The Spartaeine genus Cocalus C.L. Koch, 1846 is a poorly studied salticid group confined to the Oriental and Australian Regions. The genus is characterized by the presence of an elevation in the posterior ocular quadrangle in both sexes and the sinuous finger-like projection resting on the male palpal retrolateral tibial apophysis [Wanless, 1981]. Currently, the genus consists of five valid species, of which the only one, $\mathrm{Co}$ calus murinus Simon, 1899, has been reported from the Indian subcontinent [Roy et al., 2016; WSC, 2018]. In the present paper, we aim to describe and illustrate a new species, Cocalus lacinia sp.n. ( $\sigma^{\top}+$ ), collected from the Wayanad Wildlife Sanctuary lying in Western Ghats in Kerala, one of the biodiversity hotspots of the world [Myers et al., 2000]. The current geographic distribution of the genus in India is mapped as well.

\section{Materials and methods}

Field photos were taken with a Canon EOS 5D Mark-III using Canon EF $100 \mathrm{~mm} \mathrm{f} / 2.8$ Macro USM Lens, Canon MP-E 65 mm 1-5x Macro Lens and Canon MT-24EX Macro Twin Lite Flash. Spiders were hand-collected, and the specimens were stored in $70 \%$ ethanol. A morphological examination was undertaken under a Leica M205 C stereomicroscope. The microphotographic images were taken by means of Leica DMC4500 digital camera attached to Leica M205 C stereomicroscope, with the software package Leica Application Suite (LAS), version 4.3.0. LAS montage facility. All measurements are in $\mathrm{mm}$. Measurement data for palps and legs are as follows: total length [femur, patella, tibia, metatarsus (except palp), tarsus]. The studied specimens are deposited in the reference collection at the Centre for Animal Taxonomy and Ecology (CATE), Department of Zoology, Christ College (Autonomous), Irinjalakuda, Kerala, India.

Abbreviations used in the text and figure plates: ALE anterior lateral eyes, AME - anterior median eyes, co copulatory opening, do - dorsal, e - embolus, ec extension of cymbium, fd - fertilization duct, $\mathrm{pl}$ - prolateral, PLE - posterior lateral eyes, PME - posterior median eyes, plv - prolateral ventral, $\mathrm{rl}$ - retrolateral, RTA retrolateral tibial apophysis, rlv - retrolateral ventral, $\mathrm{t}$ tegulum, v - ventral, VTA - ventral tibial apophysis, vto ventral tibial outgrowt. The terminology follows Reiskind [1969]; that for leg spination follows the format by Bossellaers \& Jocque [2000]. 

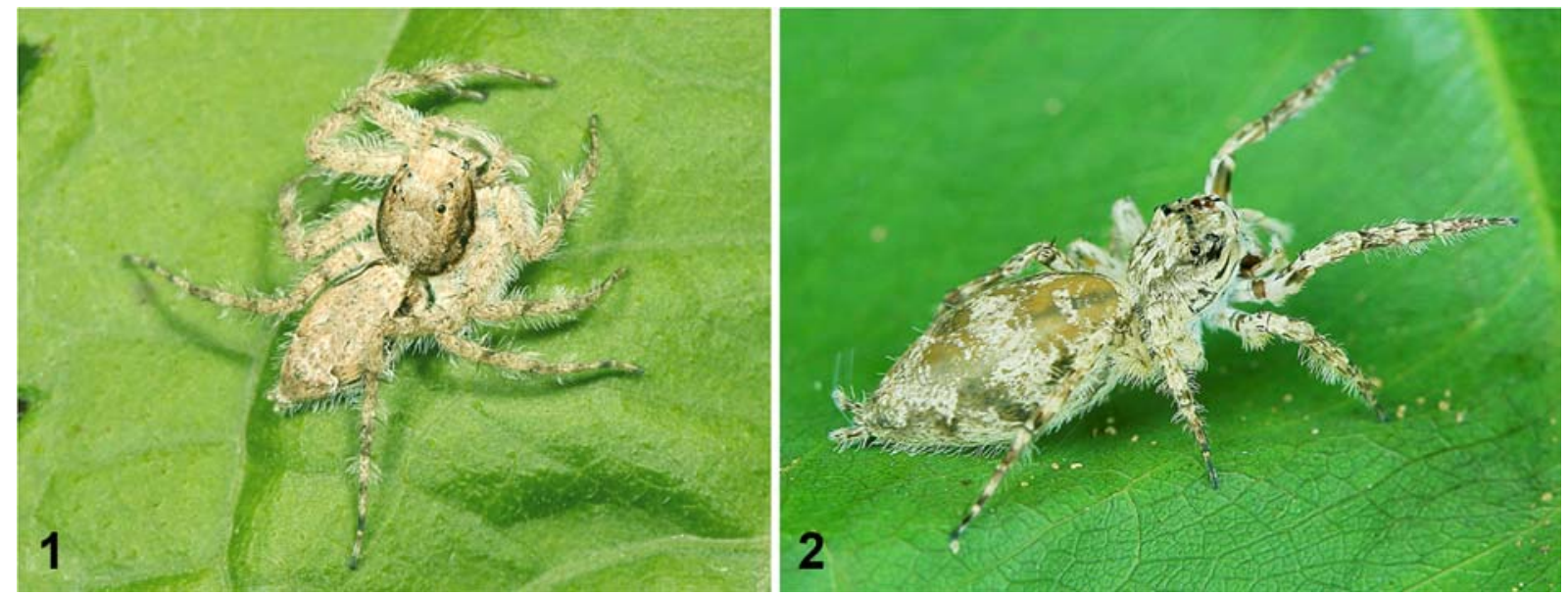

Figs 1-2. General appearance of Cocalus lacinia sp.n. from the Wayanad Wildlife Sanctuary, Kerala, India: 1 - holotype male, dorsal view; 2 - paratype female, dorsal view.

Рис. 1-2. Общий вид Cocalus lacinia sp.n. из Уэйнадского заповедника, Керала, Индия: 1 - самец голотип, сверху; 2 - самка паратип, сверху.

\section{Description}

Genus Cocalus C.L. Koch, 1846

Type species: C. concolor C.L. Koch, 1846

\section{Cocalus lacinia sp.n.}

Figs 1-19, Map.

TYPE. Holotype $\sigma^{7}$ (CATE, 8402A) from the Wayanad Wild-

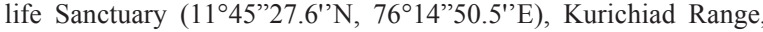
Wayanad District, Kerala, India, $916 \mathrm{~m}$ a.s.1., 10.06.2015, P.P. Sudhin \& K.S. Nafin.

PARATYPE: INDIA: 1 (CATE, 8402B), the same locality

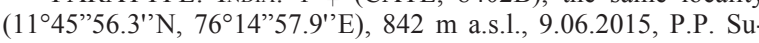
dhin \& K.S. Nafin.

ETYMOLOGY. The specific epithet is a noun in apposition originated from the Latin word lacinia, meaning a flap and referring to the presence of a flap-like structure on the basal tibia of the male palp.

DIAGNOSIS. The male of C. lacinia sp.n. is similar to that of C. gibbosus Wanless, 1981 from Australia (Queensland), but differs from it in the following combination of characters: the embolus is positioned almost vertically at the distal end of the tegulum (slightly shifted retrolaterally in $C$. gibbosus); the VTA thumb-shaped, with a sub-acute tip (more stout and truncate in C. gibbosus); the palpal tibia basally with a flap-like ventral outgrowth (which is absent from $C$. gibbosus). The female of C. lacinia sp.n. is closest to that of $C$. menglaensis Cao, Li et Żabka, 2016 from China (Yunnan), but can be distinguished by the following characters: the abdomen elongated and robust (slightly shorter and linear in $C$. menglaensis); the epigynal plate without prominent posterior projections (prominent, heavily sclerotized and rectangular in $C$. menglaensis); the copulatory openings are located posteriorly (slightly below the middle area in $C$. menglaensis); the spermathecae globular, with a posterior triangular extension (phaseoliform, without posterior triangular extension in $C$. menglaensis) (cf. figs 7, 8, 12, 14-16, 18-19 with figs 4C-D in Wanless [1981], fig. 4 in Davies \& Zabka [1989], and figs 18 A-B, D-E in Cao et al. [2016]).

DISTRIBUTION. The type locality only (Map).
DESCRIPTION. Male (holotype; Figs 1, 3-6, 11-13, 16-17). Measurements: body length 8.32 . Carapace length 3.62 , width (at the middle) 2.47 , height at PLE 1.79. Abdomen length 4.41, width (at the middle) 1.81. Ocular area length 1.81, width 2.02. Eye diameters: AME 0.59, ALE 0.29, PME 0.16, PLE 0.31. Eye interdistances: AME-ALE 0.08, PME-PME 1.64, ALE-ALE 1.34, PME-PLE 0.47, PLE-PLE 1.64, ALE-PME 0.48. Clypeus height 0.32. Length of chelicera 1.01. Palp and leg measurements: palp 3.12 $[0.84,0.59,0.52,1.17]$, leg I $8.51[2.14,1.2,2.28,1.88$, $1.01]$, II 9.49 [2.41, 1.09, 2.69, 2.29, 1.01], III 7 [1.96, 0.78, $1.76,1.63,0.87]$, IV 9.23 [2.48, 1.05, 2.24, 2.42, 1.04]. Leg formula: 2413. Spination. Palp: femur rl 1, do 2, pl 1; tarsus rl 1 pl 1; Legs: femur I-II rl 1 do 3 pl 2, III-IV rl 1 do 3 pl 2; patellae I-IV rl $1 \mathrm{pl} \mathrm{1;} \mathrm{tibia} \mathrm{I-II} \mathrm{rl} 3$ rlv 3 do 3 pl 3 plv 3 , III-IV rl 3 rlv 3 do 2 pl 3 plv 3 ; metatarsi I-II rl 3 rlv 2 do 1 pl 2 plv 1 v 1, III-IV rl 3 rlv 2 do 1 pl 3 plv 2 v 1; tarsi I-IV spineless. Carapace light yellowish brown, covered with white, brown and black setae, laterally with a white band extending from ALE to the rear end, narrowing towards it; carapace margins with a row of small black hairs (Figs 3, 6); eye field covered with chocolate white hairs; fovea light reddish brown, situated just behind PLEs (Fig. 3); clypeus low, vertical, covered with long white setae (Fig. 5); chelicerae light reddish brown, sub-vertical, frontal face with brown and white hairs (Fig. 5), pro- and retromargins with three teeth, fangs medium-sized, reddish brown; endites yellowish brown, with dull white inner tips and dark grey hairs on inner margin, margin of endites with narrow dark brown lines (Fig. 4). Labium light brown, scopulate, with a dull white tip. Sternum almost oval, yellowish brown, covered with brown and white hairs (Fig. 4). Pedicel light yellowish, with reddish-brown lateral stripes (Figs 3,6). Abdomen pale yellow, ovoid, posteriorly narrowing, covered with black and white hairs, dorsally with irregular light brown transverse patches, laterally with continuous irregular black stripes (Figs 3, 6). Venter yellowish brown, covered with numerous brown hairs, its posterior tip with dense white hairs (Fig. 4). Spinnerets yellowish brown, covered with dark brown hairs. Legs yellow, covered with hairs, setae and spines, all trochanters with a row of prolateral and retrolateral black setae, tarsal claw with eleven teeth. 


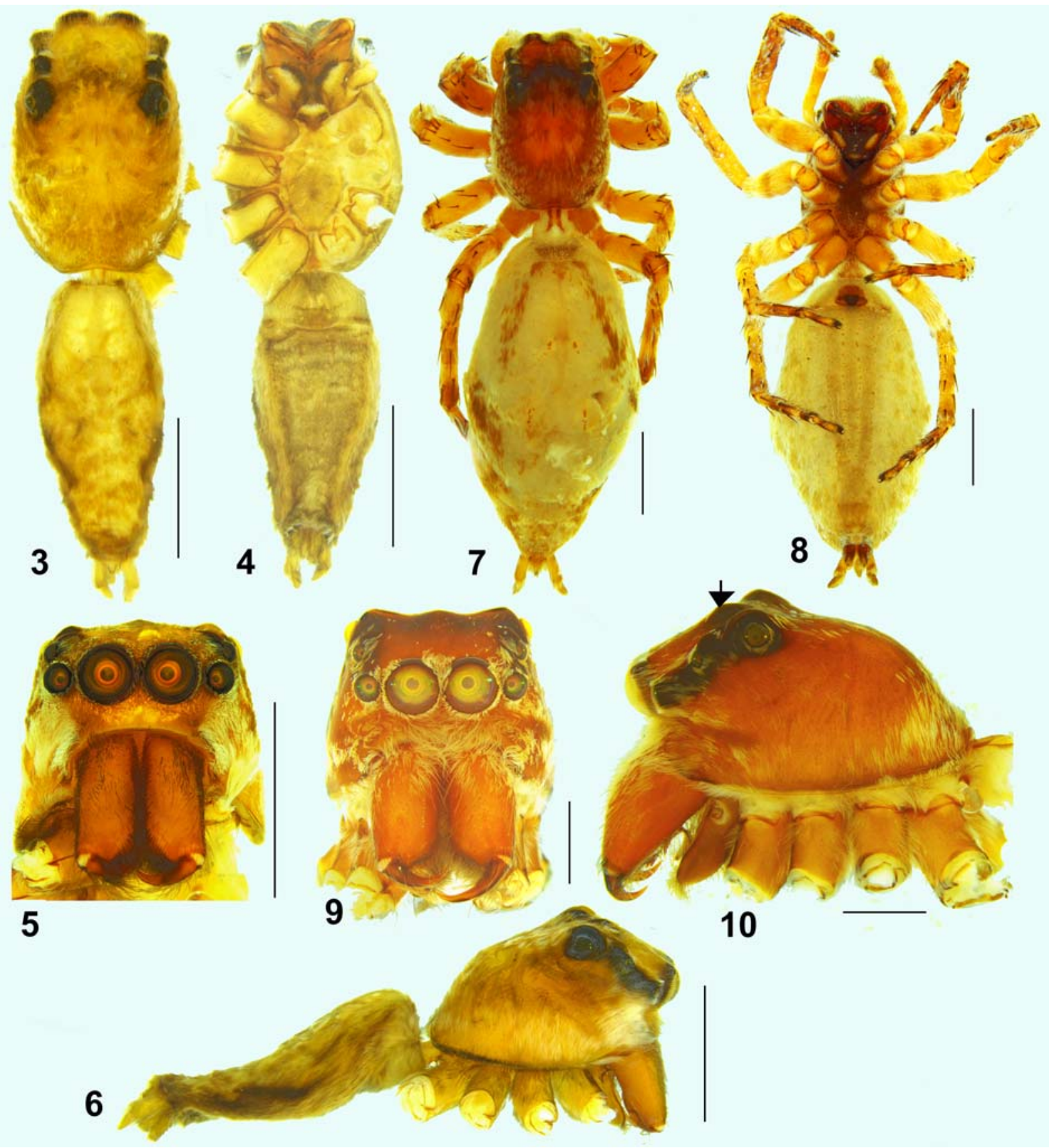

Figs 3-10. Somatic characters of Cocalus lacinia sp.n., holotype male (3-6) and paratype female (7-10): 3, 7 — body, dorsal view; 4, 8 - ditto, ventral view; 5, 9 - carapace, frontal view; 6 - body, lateral view; 10 - carapace, lateral view. Scale bar: (3-6, 7-8) $2 \mathrm{~mm}$, (9-10) $1 \mathrm{~mm}$.

Рис. 3-10. Соматические признаки Cocalus lacinia sp.n., самец-голотип (3-6) и самка-паратип (7-10): 3, 7 - тело, сверху; 4, 8 - то же, снизу; 5, 9 - головогрудь, спереди; 6 - тело, сбоку; 10 - головогрудь, сбоку. Масштаб: (3-6, 7-8) 2 мм (9-10) 1 мм.

Palp as shown in Figs 11-13, 16-17. Palp moderately long, pale yellowish, densely covered with hairs; tibia base with a flap-like ventral outgrowth, which is retrolaterally oriented (Figs 12, 16); VTA thumb like, wide at the base, with sub-acute tip (Figs 12, 16: vto); RTA dark reddish brown, with wide sinuous edge (Figs 12-13, 16-17: rta); cymbium broad, moderately long, distally truncate, with posterior triangular extension (Fig. 12: ec); tegulum ovoid, light brown with tegular furrow, retrolateral striae and dark reddish brown peripheral seminal duct (Figs 12, 16); embolus robust, hook-shaped, with the pointed tip curving inwards, towards the alveolar cavity (Figs 12-13, 16-17: e).

Female (paratype; Figs 2, 7-10, 14-15, 18-19): Measurements: body length 12.71 . Carapace length 3.88 , width (at the middle) 2.83, height at PLE 2.25. Abdomen length 8.34 , width (at the middle) 4.01 . Ocular area length 1.72 , width 2.21. Eye diameters: AME 0.66, ALE 0.33, PME 0.22, PLE 0.32. Eye interdistances: AME-ALE 0.09, PME- 

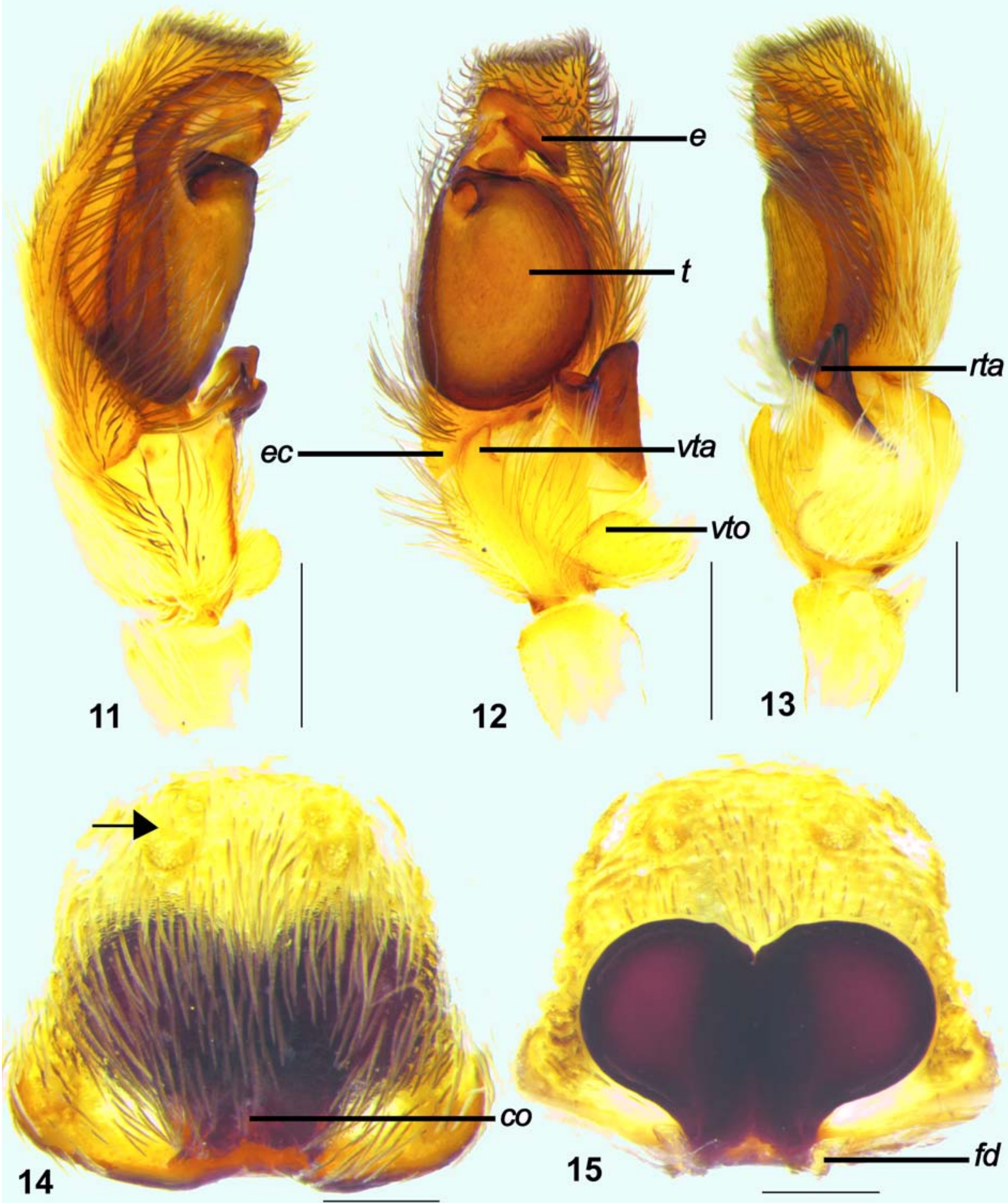

Figs 11-15. Copulatory organs of Cocalus lacinia sp.n. (holotype male and paratype female): 11 - male left palp, prolateral view: 12 ditto, ventral view; 13 - ditto, retrolateral view; 14 - epigyne, ventral view; 15 - spermathecae, dorsal view. Scale bar: (11-13) $0.5 \mathrm{~mm}$, (14-15) $0.2 \mathrm{~mm}$.

Рис. 11-15. Копулятивные органы Cocalus lacinia sp.n. (самец-голотип и самка-паратип): 11 - левая пальпа самца, спередисбоку: 12 - то же, снизу; 13 - то же, сзади-сбоку; 14 - эпигина, снизу; 15 - сперматека, сверху. Масштаб: (11-13) 0,5 мм, (1415) 0,2 мм.

PME 1.73, ALE-ALE 1.47, PME-PLE 0.32, PLE-PLE 1.88, ALE-PME 0.31. Clypeus height 0.35. Length of chelicera 1.51. Palp and leg measurements: palp $3.81[1.08,0.62$, $0.77,1.34]$, leg I $8.11[2.28,1.30,2.18,1.49,0.86]$, II 7.73
$[2.21,1.21,1.99,1.44,0.88]$, III 7 [2.21, 0.83, 1.88, 1.40, $0.68]$, IV 10.03 [2.72, 1.19, 2.43, 2.68, 1.01]. Leg formula: 4123. Spination. Palp: femur rl 1 do 2 pl 1 , tibia rl 1 , tarsus rl 2 rlv 1 pl 1 plv 1 v 1; Legs: femur I-II rl 3 do 3 pl 2, III-IV 

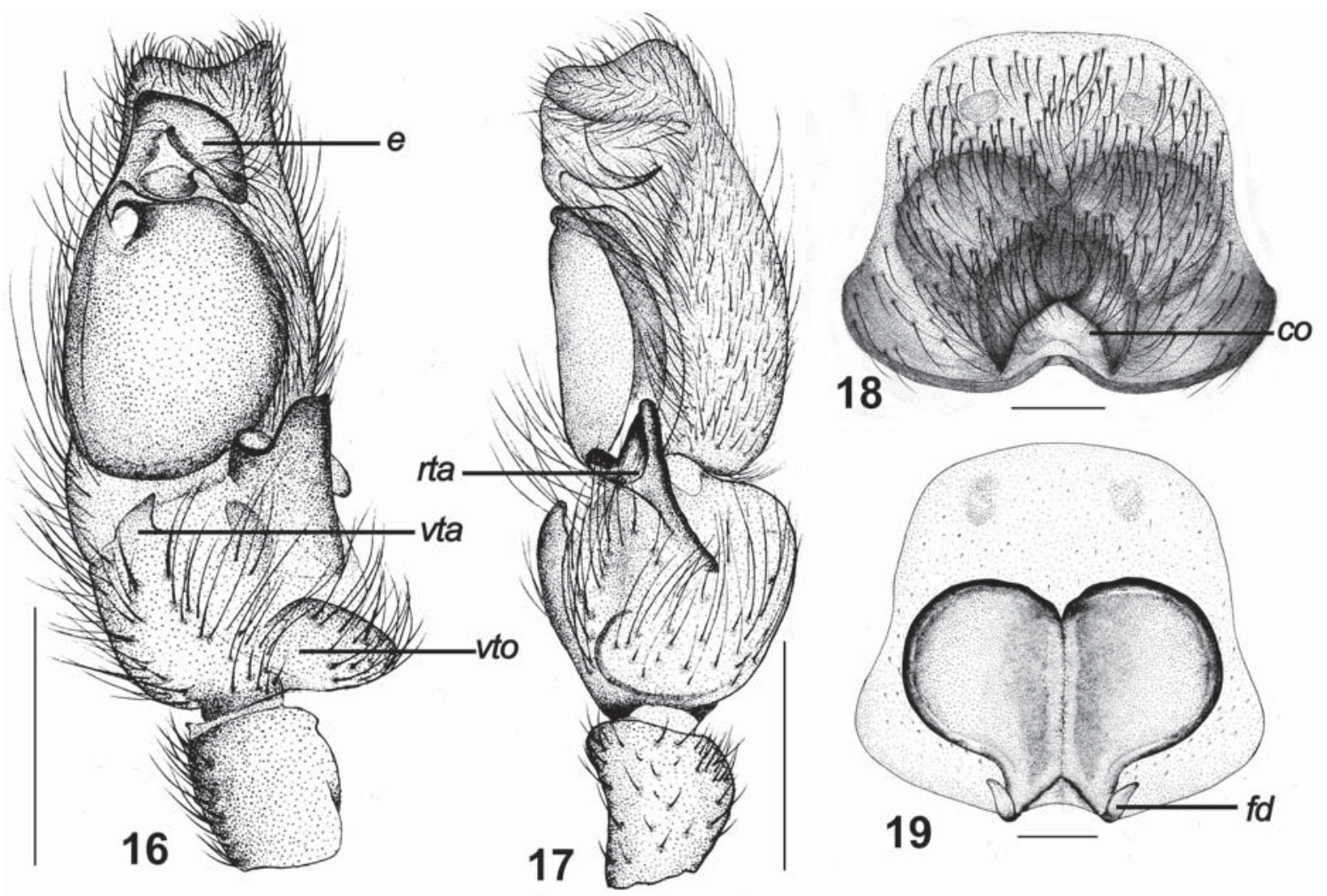

Figs 16-19. Copulatory organs of Cocalus lacinia sp.n. (holotype male and paratype female): 16 - male left palp, ventral view; 17 ditto, retrolateral view; 18 - epigyne, ventral view; 19 - spermathecae, dorsal view. Scale bar: (16-17) $0.5 \mathrm{~mm}$, (18-19) $0.2 \mathrm{~mm}$.

Рис. 16-19. Копулятивные органы Cocalus lacinia sp.n. (самец-голотип и самка-паратип): 16 - левая пальпа самца, снизу; 17 то же, сзади-сбоку; 18 - эпигина, снизу; 19 - сперматека, сверху. Масштаб: (16-17) 0,5 мм, (18-19) 0,2 мм.

rl 2 do 2 pl 3; patellae I-IV rl 1 pl 1; tibia I-II rl 3 rlv 3 do 3 pl 3 plv 3, III-IV rl 3, rlv 3 do 2 pl 3 plv 3; metatarsi I-II rl 3 rlv 1 do 1 pl 3 plv 1 , III-IV rl 2 rlv 2 do 1 pl 2 plv 2 v 1 ; tarsi I-IV spineless. In all respects as the male, except as follows: carapace light reddish brown, covered with white setae, more elongate and appressed in the ocular quadrangle, margin of carapace with narrow dark reddish brown lines, region around the posterior quadrangle with a wide inverted V-shaped black mottling (Fig. 7); posterior ocular quadrangle elevation more prominent (arrowed in Fig. 10); fovea distinct, longitudinal, dark reddish-brown (Fig. 7); clypeus light reddish brown, densely covered with white hairs (Fig. 9); chelicerae reddish brown, promargin with three teeth and retromargin with four teeth; labium dark brown, maxillae and sternum light brown (Fig. 8). Abdomen more elongated, slightly robust, pale yellow, covered with white and brown setae, dorsally with a median light brown longitudinal stripe terminating at the middle, laterally with continuous irregular similar coloured stripes (Fig. 7). Venter pale yellow, medially with three longitudinal light greyish brown stripes and four longitudinal light brown dot lines (Fig. 8). Anterior and median spinnerets light yellowish brown, posterior spinnerets light brown. Epigyne as shown in Figs 14-15, 18-19. Epigyne bell-shaped, golden-light brown, covered with long creamy hairs, posterior borderline with a median invagination (Figs 14, 18), anteriorly with a pair of kidney-shaped thickenings (arrowed in Fig, 14); copulatory openings at the lateral margins of the posterior triangular groove (Figs 14,
18: co); spermathecae massive, globular, dark reddish brown, compact, with posterior triangular extension (Figs 15, 19); insemination duct short, entering the spermathecae midventrally; fertilization duct short, anterolaterally oriented, located at the posterior tip of the spermathecae (Figs 15, 19: fd).

HABITAT. The studied specimens were collected from the bark of Tectona grandis (Lamiaceae) in the Teak plantation of the Wayanad Wildlife Sanctuary, Kerala, India.

Acknowledgements. The authors are grateful to $\mathrm{Dr}$ Mathew Paul Ukken, the Principal of the Christ College (Autonomous), Irinjalakuda, Kerala, for providing us with the facilities for undertaking this study. Our sincere thanks go to Prof Jerzy Prószyñski for his valuable suggestions and encouragement that greatly improved this work. We are immensely grateful to Dr Dmitri V. Logunov of The Manchester Museum (UK) for his editorial help and to anonymous reviewers for their help in improving the ms. We are thankful to the Principal Chief Conservator of Forests, Kerala, for issuing the collecting permit. Many thanks are due to $\mathrm{Mr}$ Alex C. J. of the Kerala Forest Research Institute, Thrissur, Kerala for preparing the distribution map. The authors are grateful to Mr Dhanesh Kumar P., Wildlife Warden, and the field staff of the Wayanad Wildlife Sanctuary, especially to Mr Krishnadas K. Rajan, Assistant Wildlife Warden, Mr Suresh Thenarambath, Forester and Mr Appu, Field watcher for the hospitality and field support. This study was funded 


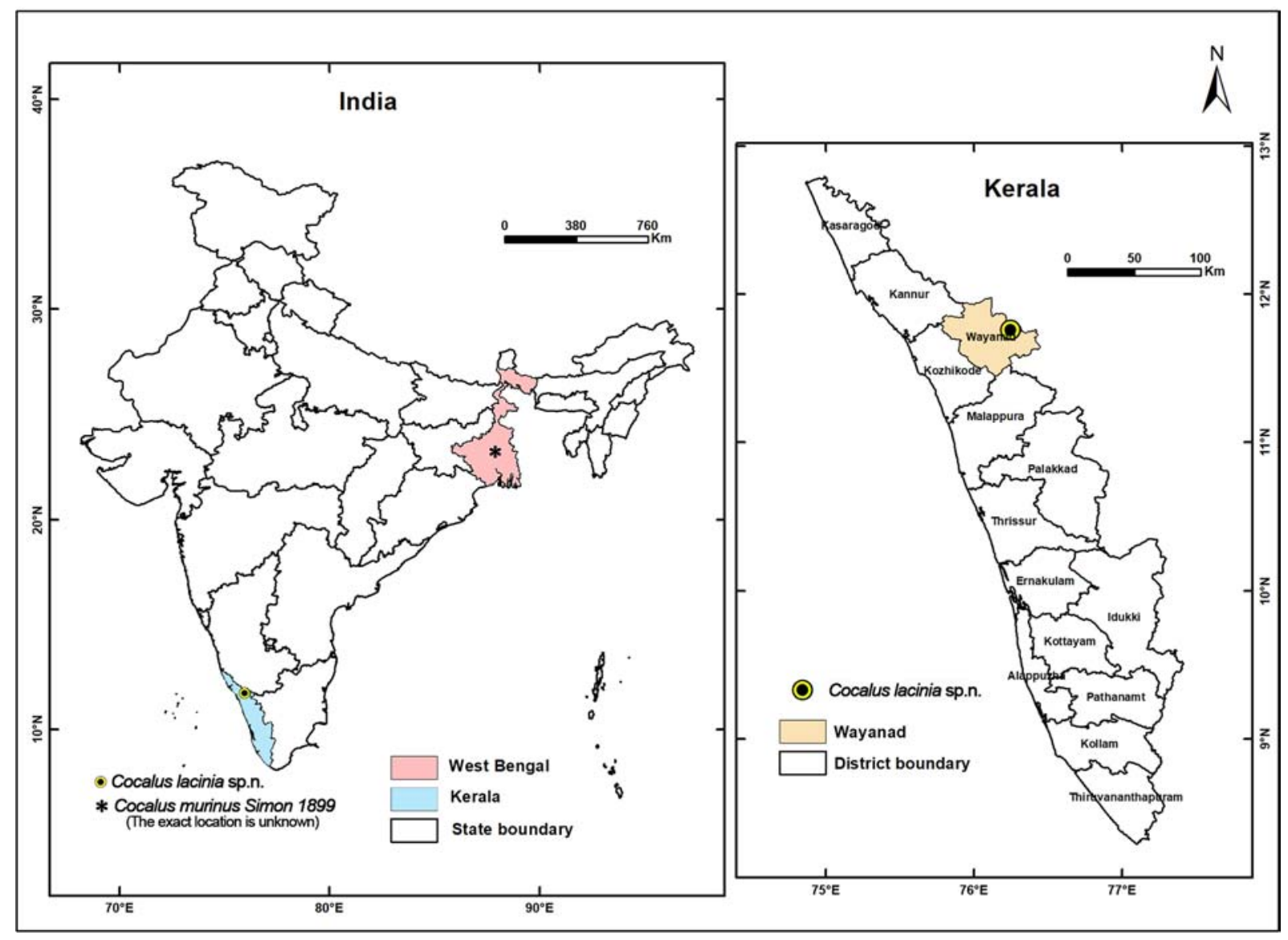

Map. Collecting localities of the genus Cocalus C.L. Koch, 1846 in India. Карта. Точки находок рода Cocalus C.L. Koch, 1846 в Индии.

by the Science \& Engineering Research Board (SERB) DST, New Delhi, under the Young Scientist Research Project: No. SB/YS/LS-86/2013.

\section{References}

Bosselaers J., Jocqué J. 2000. Studies in Corinnidae: transfer of four genera and description of the female of Lessertina mutica Lawrence 1942 // Tropical Zoology. Vol.13. P.305-325.

Cao Q., Li S., Żabka M. 2016. The jumping spiders from Xishuangbanna, Yunnan, China (Araneae, Salticidae) // ZooKeys. Vol.630. P.43-104.

Davies V.T., Żabka M. 1989. Illustrated keys to the genera of jumping spiders (Araneae: Salticidae) in Australia // Memoirs of the Queensland Museum.Vol.27. P.189-266.

Myers N., Mittermeier R.A., Mittermeier C.G., da Fonseca G.A.B.

Kent J. 2000. Biodiversity hotspots for conservation priorities // Nature. Vol.403. P.853-858.
Reiskind J. 1969. The spider subfamily Castianeirinae of North and Central America (Araneae, Clubionidae) // Bulletin of the Museum of Comparative Zoology. Vol.138. P.163-325.

Roy T.K., Saha S., Raychaudhuri D. 2016. A treatise on the jumping spiders (Araneae: Salticidae) of tea ecosystem of Dooars, West Bengal, India // World Scientific News. Vol.53. No.1. P.1-66.

Wanless F.R. 1981. A revision of the spider genus Cocalus (Araneae: Salticidae) // Bulletin of the British Museum of Natural History (Zool.). Vol.41. P.253-261.

WSC 2018. World Spider Catalog. Natural History Museum Bern, online at http://wsc.nmbe.ch,version 19 (accessed on 7th November 2018).

Responsible editor D.V. Logunov 